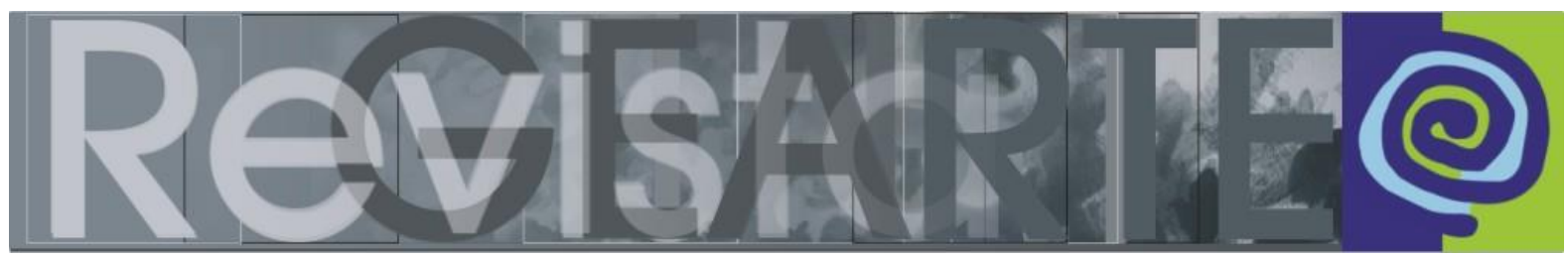

ISSN 2357-9854 | e-ISSN 2596-3198 (online)

\title{
Entre el saber y el poder: mujeres en el contexto del arte actual en la región sur de Colombia
}

\author{
Rocío Polanía Farfán \\ (Universidad Surcolombiana — USCO, Neiva, Huila, Colombia)
}

\begin{abstract}
RESUMEN - Entre el saber y el poder: mujeres en el contexto del arte actual ${ }^{1}$ en la región sur de Colombia $^{2}$ - La mujer desde siempre ha sido objeto de discriminación, exclusión y desigualdades, no solo por las cuestiones de género, sino también, por la evidente interconexión o difícil separación entre las variables de etnia/raza, sexo/género y clase social. En este sentido la relación sexualidad/poder se considera un efecto productivo de discursos, poderes, resistencias, estrategias, dispositivos, conocimientos, exclusiones, sometimientos, empoderamientos culturales y corporales dominantes, entre otros; en suma, es algo estrictamente político. Sin embargo, llama poderosamente la atención la posición crítica y contrahegemónica que han asumido las mujeres para interpelar y subvertir los sistemas de dominación patriarcal, para dar paso a su participación en los espacios políticos, económicos, sociales, culturales y artísticos. En vista de esto, para el desarrollo del tema del presente texto, se han tomado como referencia a cinco mujeres que proceden de la Región Sur de Colombia, que con seguridad han traspasado diferentes geografías, fronteras y mapas de poder a través de la fotografía, el performance, los medios audiovisuales, la instalación, la escultura para situarse en una posición de reflexión y resistencia y no bajo el amparo del discurso de la inclusión del Otro.
\end{abstract}

Palabras claves

Arte. Poder. Saber. Resistencia. Mujer Indigena.

RESUMO - Entre o saber e o poder: mulheres no contexto da arte atual na região sul da Colômbia - As mulheres sempre foram alvo de discriminação, exclusão e desigualdades não apenas por questões de gênero, mas também pela evidente interconexão ou difícil separação entre as variáveis

1 El arte indígena actual hace referencia a aquellas expresiones artísticas desarrolladas de manera paralela y simultanea con los sistemas estéticos globales, que ponen de manifiesto la existencia de creadores que encuentran en las prácticas del arte "contemporáneo", las maneras de reconectar con la esencia de la cultura, restablecen dialogo entre la percepción individual y la colectiva, pero además, se convierten en formas de resistencia estéticas y culturales ante los discursos y representaciones de las hegemonías totalizantes y excluyentes del mundo actual. Según Juan Coronel Rivera "el arte indígena actual está determinado por sus cualidades estéticas, no por el hecho de ser indígena". Ingrid Suckaer explicó que "hay muchos artistas que están haciendo esta labor de salirse del canon, de trabajar con su propio lenguaje, de seguir amarrados, unidos con sus raíces fuertes hacia su mundo originario, hacia su mundo indígena, hacia ese mundo metafísico, pero a la vez se están abriendo a una lectura, a un dialogo a escala internacional". Desde esta perspectiva los artistas indigenas actuales, utilizan técnicas, formatos y soportes propios del arte contemporáneo para exteriozar la presencia de las tradiciones artísticas de los pueblos a los que pertenecen. Son hoy, los mismos artistas indígenas, educados en Universidades y escuelas de arte de corte occidental, quienes revalidan, actualizan, canalizan y transforman el concepto "arte" y lo hacen propiamente suyo, lo revitalizan en la cotidianidad para conceptualizarlo como "arte indígena". Disponible en: <https://www.jornada.com.mx/2017/03/30/cultura/a06n2cul>

2 La Región Sur está conformada por "Ios Departamentos del Cauca, Caquetá, Huila, Nariño, Putumayo y Tolima, estos departamentos constituyen una región geográfica social y cultural ubicada al sur y occidente de la República de Colombia.

POLANÍA FARFÁN, Rocío. Entre el saber y el poder: mujeres en el 


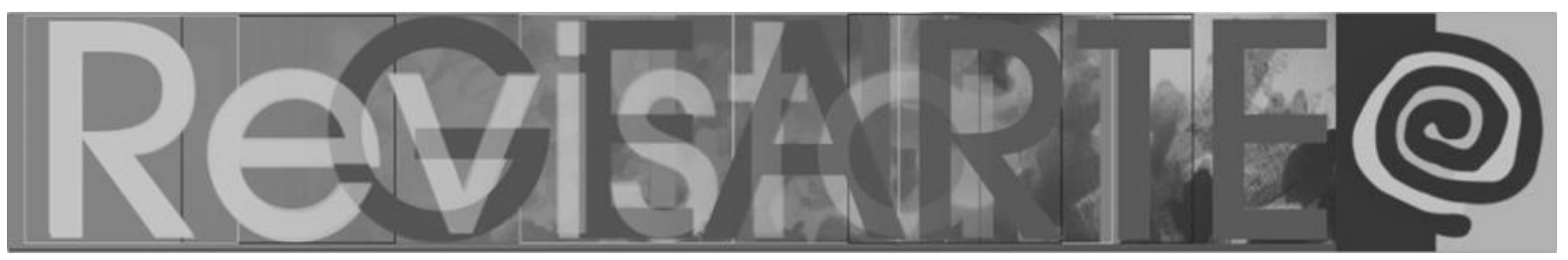

etnia/raça, sexo/gênero e classe social. Nesse sentido a relação sexualidade/poder é considerada um efeito produtivo de discursos, poderes, resistências, estratégias, dispositivos, conhecimentos, exclusões, submissões, empoderamentos culturais e corporais dominantes, entre outros, enfim é algo estritamente político. No entanto, chama a atenção a posição crítica e contra-hegemônica que as mulheres têm assumido para desafiar e subverter os sistemas patriarcais de dominação, para sua participação nos espaços políticos, econômicos, sociais, culturais e artísticos. Em vista disso, para o desenvolvimento do tema do presente texto, foram tomadas como referência cinco mulheres provenientes da Região Sul da Colômbia, que atravessaram diferentes geografias, fronteiras e mapas de poder através da fotografia, da performance, dos meios audiovisuais, da instalação, da escultura para situarem-se numa posição de reflexão e resistência e não sob a proteção do discurso da inclusão do Outro.

Palavras-chave

Arte. Poder. Conhecer. Resistência. Mulher Indígena.

Kate Millet afirma que el sexo es una categoría social que se reviste de un carácter político (MILLET,1995, p. 68), esto es así porque siempre ha estado sujeto a las relaciones de poder, dominación y subordinación. En este sentido la dicotomía sexual es un discurso de diferencia construido a partir de los entramados o dispositivos que la producen y agrupan a los sujetos, en términos taxativamente sexuales de acuerdo con la categoría más antigua de oposición hombre/mujer. Desde esta perspectiva se afirma que los sujetos se diferencian principalmente por el sexo situando sistemáticamente a la mujer en la punta de la diferencia, como un ser inferior respecto a los hombres. En esta situación es vinculada prácticamente a la trama de los dispositivos de poder ${ }^{3}$ que operan como mecanismos problematizadores de identidades, relaciones, e instituciones sociales y discursos.

La sexualidad no es simplemente una referencia biológica intrínseca en el hombre, sino que es una construcción que se ha estructurado a través de diferentes dispositivos disciplinarios de poder; por tanto, puede ser considerada una de las tantas estrategias en que el poder circula. En este sentido, la relación sexualidad/poder se considera un efecto productivo de discursos, poderes, resistencias, estrategias,

3 Foucault, con la palabra poder se refiere a: 1) "(...) la multiplicidad de las relaciones de fuerza inmanentes y propias del campo en que se ejercen, y que son constitutivas de su organización"; 2) "(...) el juego que por medio de luchas y enfrentamientos incesantes las transforma, las refuerza, las invierte"; además a "(...) los apoyos que dichas relaciones de fuerza encuentran las unas en las otras"; y 3 ) "(...) las estrategias que las tornan efectivas y cuyo dibujo general o cristalización toma forma en los aparatos estatales, en la formulación de la ley y en las hegemonías sociales." (FOUCAULT, 2010. p. 89). 


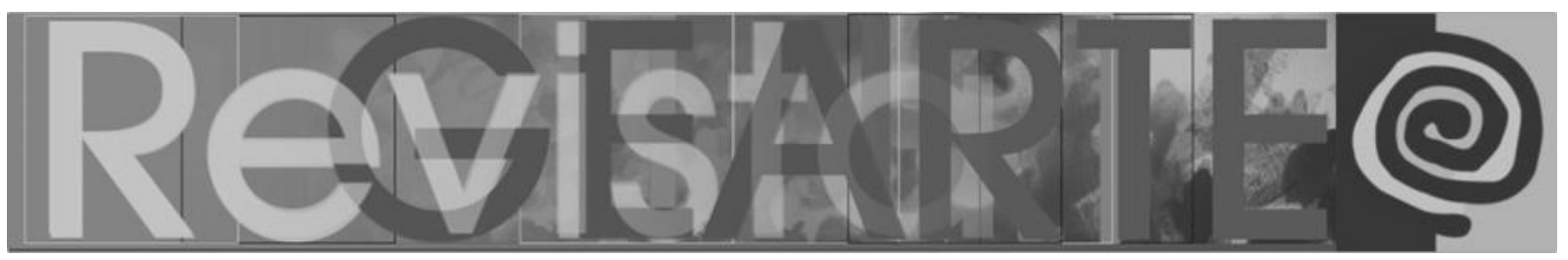

dispositivos, conocimientos, exclusiones, sometimientos, empoderamientos culturales y corporales dominantes, entre otros. Es estrictamente política.

El poder es dinámico y está en todas partes, afirma Foucault; ocupa todo, adopta diferentes mecanismos que van cambiando a través del tiempo y el espacio. En este sentido, el poder no es ajeno al sujeto. Existen diversos canales a través de los cuales el poder llega a las conductas individuales de los miembros de la sociedad para controlar las prácticas de placer cotidiano. Al respecto, Butler afirma que "el proceso de asumir el poder no consiste sencillamente en cogerlo de un lado, transferirlo intacto y enseguida convertirlo en propio; el acto de apropiación puede conllevar una modificación tal que el poder asumido o apropiado acabe actuando en contra del poder que hizo posible esa asunción" (BUTLER, 2010, p. 20). Sin embargo, en una sociedad crecientemente incluyente se asume el poder como una red que transitamos, transmitimos, aceptamos, accedemos, y ostentamos o consentimos de manera total o parcial. Así, Hanna Arendt afirma que "el poder corresponde a la capacidad humana no sólo de actuar sino de actuar en concierto. El poder no es nunca propiedad de un individuo, pertenece al grupo y existe sólo mientras éste no se desintegra" (ARENDT, 2005, p. 60)

Desde siempre el poder ha estado ligado a la hegemonía dominante de la masculinidad, expresada en el monologuismo que otorga la universalidad y la verdad a un discurso social impuesto. Solo se interrumpe a principios del siglo XX por el discurso del sexo femenino contra las hegemonías ejercidas por el sistema de dominación patriarcal. El poder asumido y apropiado por el sexo femenino por tradición actúa, en determinado momento, como un contra-discurso que implica el deseo de cambio y de irrupción en búsqueda de un orden social y cultural incluyente, abierto al desarrollo de las potencialidades humanas tanto de mujeres como de hombres. Se trata, en sí, de hacer efectivo el cambio de aquellas ideologías que han mantenido el discurso de las hegemonías por miles de años, reprimiendo la transformación de una forma de vida entendida como diferente a la del modelo establecido por la misma sociedad. Sin embargo, siempre existe un intersticio dentro 


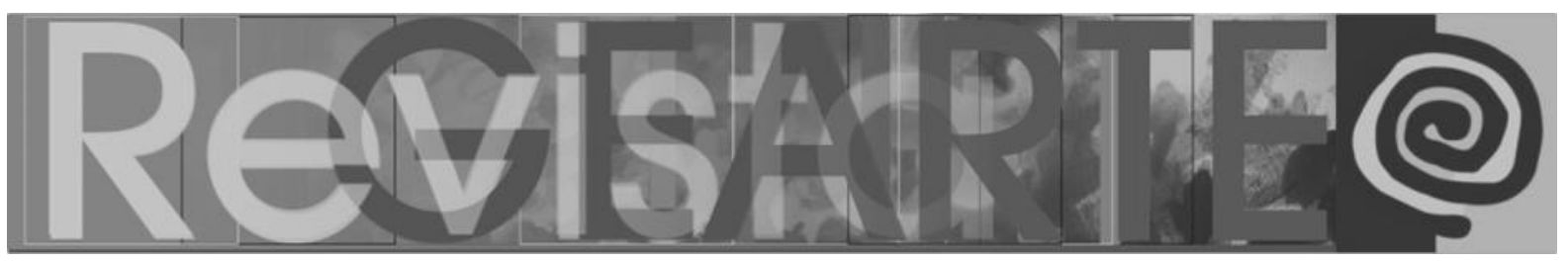

del marco social regulatorio que permite desafiar, y eventualmente cambiar, las reglas explícitas e implícitas del orden social vigente.

Pero cómo tratar la diferencia sexual sin hacer referencia al Otro, al extremo otro de una oposición entre sexos situada apropiadamente para sustentar un sistema de poder. La mujer no es ya solo diferente, sino diferente para poner en práctica nuevos valores. Es un sujeto, no el Otro, porque si es el otro seguiríamos repitiendo el discurso de la discriminación y la desigualdad. Es el otro siempre y cuando se mire en el espejo del Otro: tanto la víctima como el victimario pueden ocupar lugares intercambiables. Se pretende entonces derribar las estructuras discursivas y sociales en que se sostiene la diferencia, la desigualdad, para de esta manera construir discursos conjuntamente a partir de una nueva ética de inclusión y respeto. Por consiguiente, comprender que "el sujeto es para-sí por-otro, es con otro, el sujeto es creador, creador de sí, del mundo, es creador permanente del nosotros que lo habita". (CAMPERO, 2017, p. 149)

En ese contexto "tiene que existir algo otro que pueda poner al sí su mismidad, porque si algo estamos diciendo cuando hablamos de sujeto es que la vida se construye y conforma de aquellas multiplicidades que son capaces cada una de distinguirse entre sí, y esto es algo que necesariamente acontece en una relación comunicativa que precisa indefectiblemente de la solidaridad entre partes para la propia identificación" (CAMPERO, 2017, p. 149). Precisamente es en la relación comunicativa que se funda entre el sí mismo y el otro donde se comparten saberes, acciones, representaciones simbólicas, que se constituyen en el seno de un contexto intersubjetivo de significaciones.

En consecuencia, la intersubjetividad implica evidentemente una autoconcepción, una concepción de los otros a quienes el actor considera sus semejantes, pero que son para él sujetos de interacción en una realidad preexistente. Solo después de muchos siglos de segregación, hoy hombres y mujeres han ido tomando conciencia de la igualdad valórica de los sexos, y, de esta manera, de la 


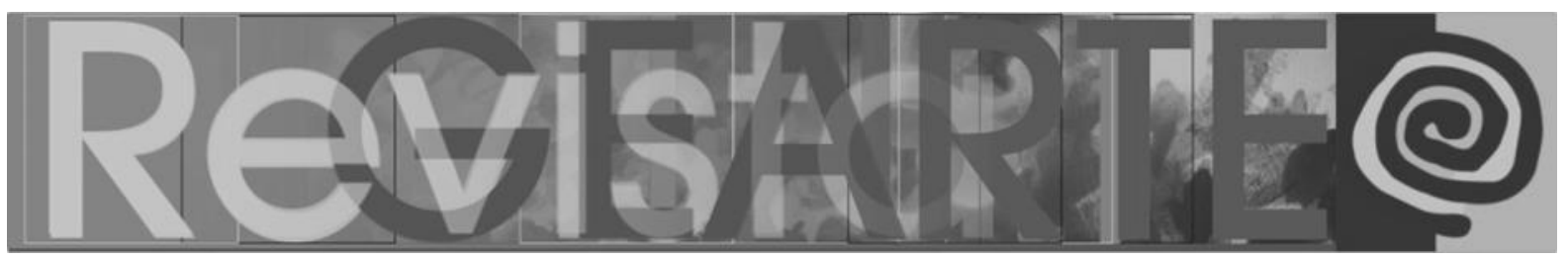

igual de importancia que tienen ambos roles, productor y reproductor, y ambas formas mentales, objetiva y subjetiva. No obstante, aún faltan muchas barreras por vencer respecto a la participación de la mujer en los diferentes campos sociales, pero, más aún, respecto al rol que desempeña como sujeto creador en el arte.

La mujer como sujeto activo en el ámbito de la creación se incorpora a un mundo no elaborado por ella, para situarse en el contexto artístico como un vector que deconstruye la mirada de aquellos que deshumanizaron su existencia a través del tiempo. En efecto, la construcción sujeto-mujer exige la existencia de un yo femenino, expresado en forma de libertad de conciencia que reclama sin equívocos su autonomía intelectual y moral. La mujer en el arte entra como sujeto enunciante al orden simbólico de las leyes, de los procesos sociales y de las instituciones. Su autonomía solo es posible cuando marca límites, crea sentidos o reinterpreta los estereotipos culturales existentes.

La visibilidad de la mujer en el arte trae consigo la desconstrucción del discurso tradicional de la historia del arte, en la medida que el papel invisible que había tenido choca con el orden de poder conferido por el deseo masculino. La mujer apropia los lenguajes del arte para comunicar tanto el mundo femenino como el masculino y sus interrelaciones. Esto permite no solo reelaborar su propia biografía sino también transgredir los modelos dominantes impuestos por la cultura patriarcal, dando lugar a la re-elaboración de un proceso de producción que libera los sentidos de la manipulación ejercida por los diferentes sistemas de poder.

La obra de Rosa Ximena Tisoy, artista indígena de la Región Sur de Colombia, ilustra lo anterior: apuesta a propiciar procesos de resistencia, disidencia, transgresión de fronteras por su misma procedencia; propone un sistema estético en el cual el uso del tiempo y el espacio son condiciones para escapar a las reglas del sistema dominante, y hacer posible la autoconstrucción de nuevos paisajes de autonomía. Es interesante observar que en la obra de Tisoy existe una constante recurrencia al territorio, a la defensa de las formas de vida y la memoria de un pueblo. En efecto, 


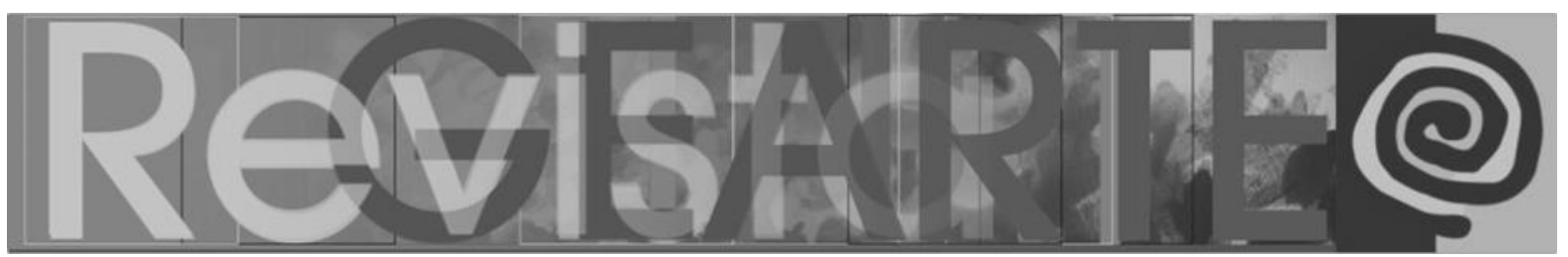

hay una materialización de significados ancestrales revestidos de contemporaneidad, así como un diálogo incesante entre tradiciones e innovación que se oponen a las diferentes formas de poder.

Figura 1 - Rosa Ximena Tisoy. Instalación sala de arte contemporáneo Popayán

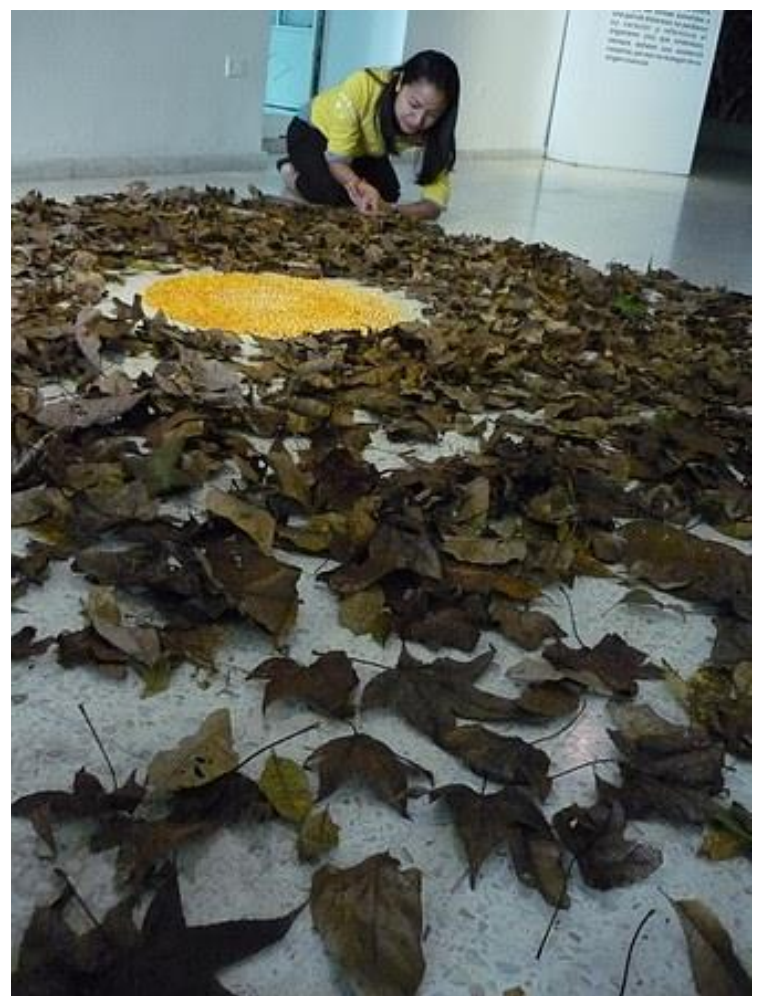

Fuente: Tisoy, Rosa. http://rosatisoy.wixsite.com/rosy-tisoy-/en-blanco. Acceso en: 9 mar. 2017.

En esta medida el proceso creativo de Tisoy basado en el lugar, el paisaje o el territorio "pueden convertirse en un hecho que in-surge, es decir, que se muestra, devela, cuestiona, problematiza, interpela el orden establecido. De esta manera, permite al sujeto creador, en cualquier instancia de la vida social, asumir el compromiso crítico de precisar su lugar de enunciación, reafirmando su condición socio-cultural, étnica, generacional, de género, de opciones sexuales, religiosas, 


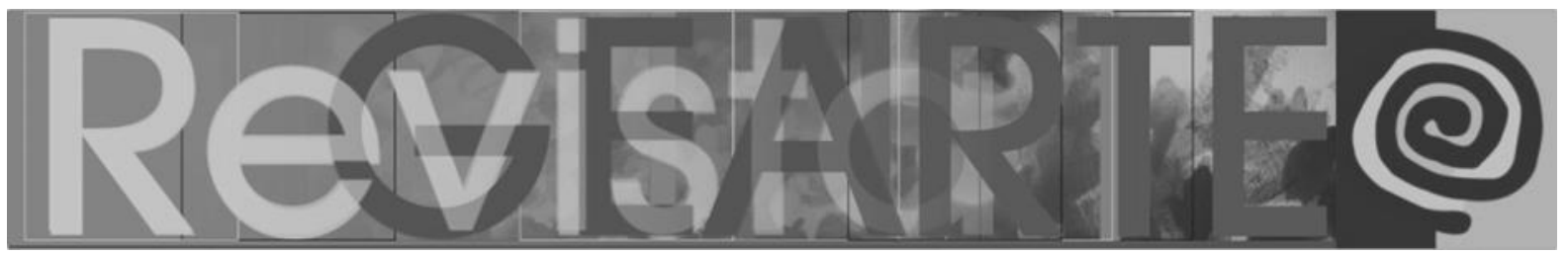

políticas, y reivindicar lo local como un acto de reafirmación de lo que nos es propio; o de lo que hacemos propio" 4 .

\section{Figura 2 - Rosa Ximena Tisoy. Instalación sala de arte contemporáneo Popayán}

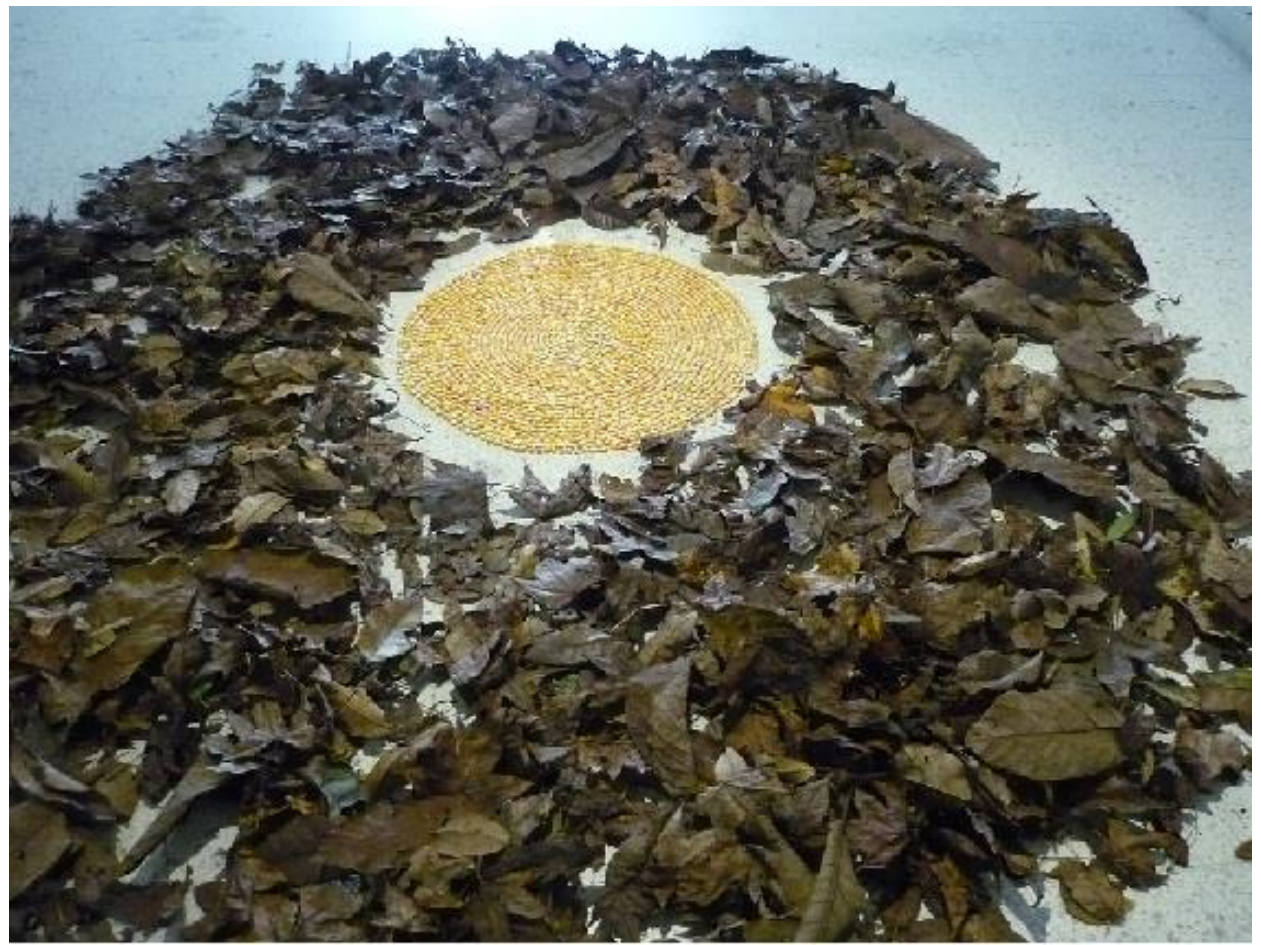

Fuente: Tisoy, Rosa. http://rosatisoy.wixsite.com/rosy-tisoy-/en-blanco . Acceso en: 9 mar. 2017.

Las narrativas visuales creadas por artistas de procedencia indígena son un desafío al poder; forman parte del complejo juego entre lo excluido y lo incluido, entre lo particular y lo universal; son un proceso que oscila desde los márgenes hacia el centro y viceversa, como un gesto que se apropia del saber para la transformación del poder. Desde esta perspectiva, la obra de Rosa Ximena Tisoy es una narrativa que se ubica en las margenes de las praxis políticas, sociales y culturales ya instituidas; por esto presupone la de diálogos interculturales críticos y necesarios en la búsqueda de tener otros espacios para el intercambio de experiencias, el desarrollo de iniciativas

4 Albán, Achinte. Adolfo. Prácticas culturales basadas en lugar e investigadores locales. http://www.territoriosonoro.org/marimba/wp-content/uploads/2011/11/Ensayo.-Prácticas-culturalesbasadas-en-lugar-e-investigadores-locales.-2013.pdf Pág. 1. Consultada 20/07/2013 


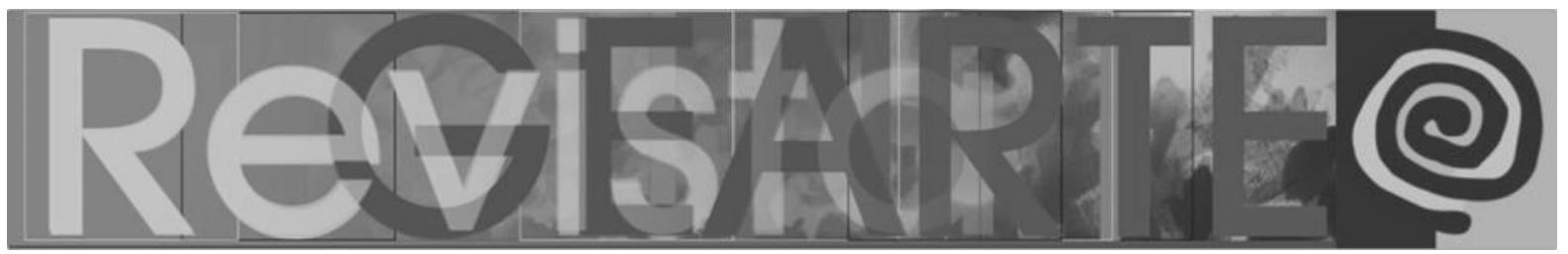

conjuntas y la visibilización de las mujeres tanto como indígenas o mestizas en el concierto internacional del arte.

Figura 3 - Rosa Ximena Tisoy. Performance apropiación de espacios

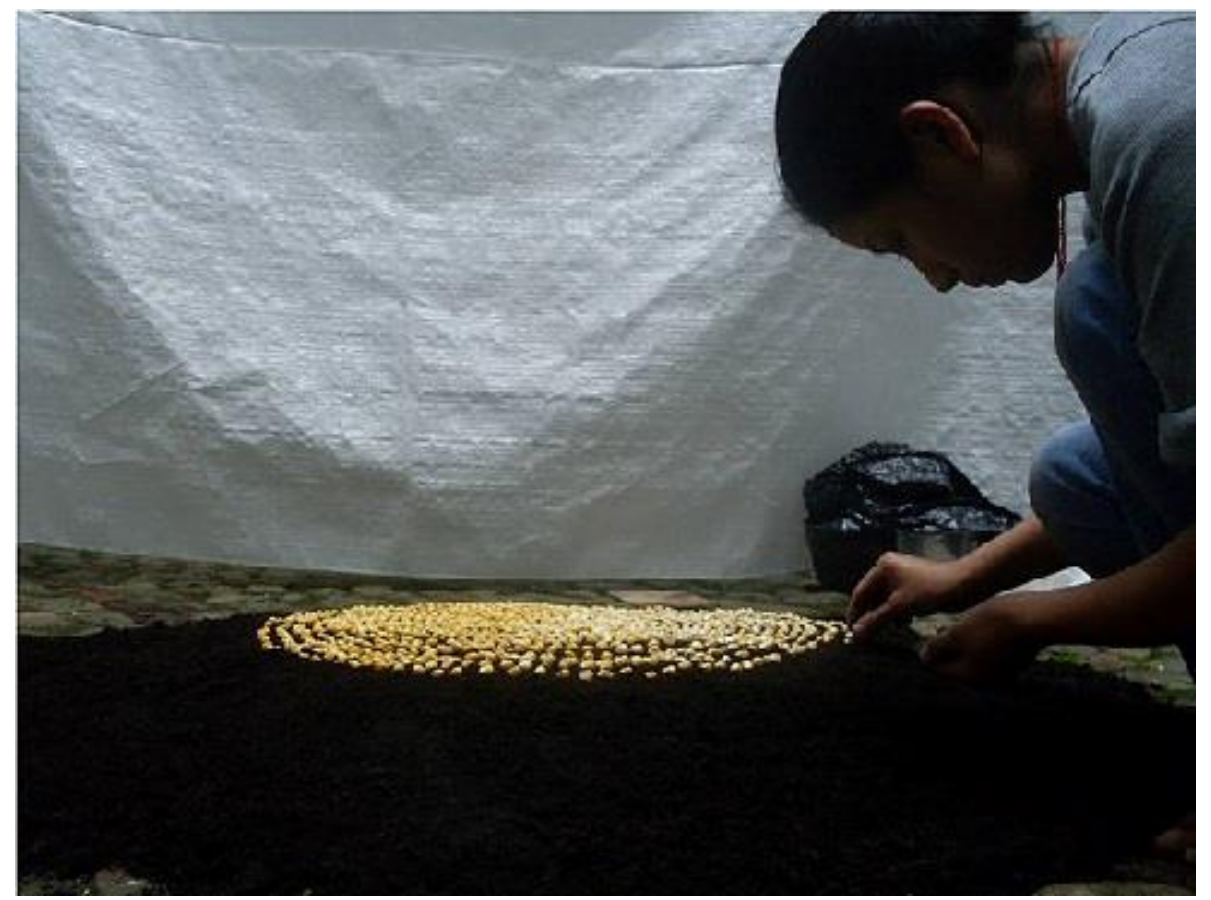

Fuente: Tisoy, Rosa. http://rosatisoy. wixsite.com/rosy-tisoy-/en-blanco?lightbox=i101 pya. Acceso en: 9 mar. 2017.

Ahora bien, en la búsqueda por encontrar otras maneras de imaginarse el mundo y pensar otros futuros posibles, las mujeres de distintos orígenes étnicos luchan diligentemente por ganar la voz que necesitan para intervenir en los tropos dominantes de la modernidad/colonialidad del arte. Tal es el caso de la propuesta realizadas por Magadalena Agreda y Pastora Chicunque, dos mujeres indígenas, que desde sus lugares de enunciación permiten mostrar la cultura desde el género y el género desde la cultura; esto significa que para ellas no existe una diferenciación de géneros en el campo de la creación artística: cada hebra cruzada, cada punto establecido en el lienzo representan el pasado, el presente y el futuro de su pueblo. Ellas tejen y entretejen redes que desentrañan relaciones e interacciones sociales y culturales del orden simbólico existententes en el espacio comunitario. 


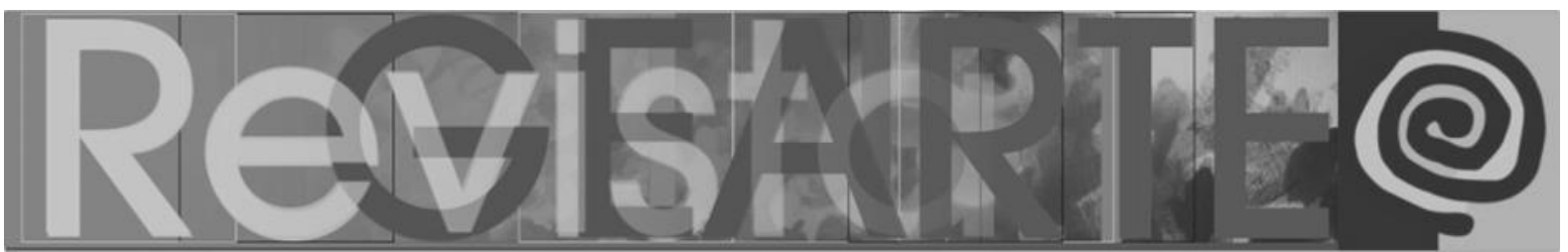

Magadalena Agreda y Pastora Chicunque, dos mujeres que viven en el Alto del Sibundoy, ubicado en el departamento del Putumayo, al sur de Colombia, penetran en un cuerpo de ideas estructuradas por la cultura Kamentsá o Kamsá, durante miles de años a través del tejido. Ellas, relatan historias surgidas de la imaginación de su madre, que mediante una grafía propia se constituyen en un sistema de signos que funcionan como guía para mantener y comunicar la memoria, las costumbres y tradiciones. Al respecto, no se trata de repetir el pasado, sino comunicar el origen y poner en actividad el poder transformativo de lo existente tal y como afirma el artista indígena Kindi Llajtu.

Figura 4 - Tejido Kamentsá o Kamsá. 2009

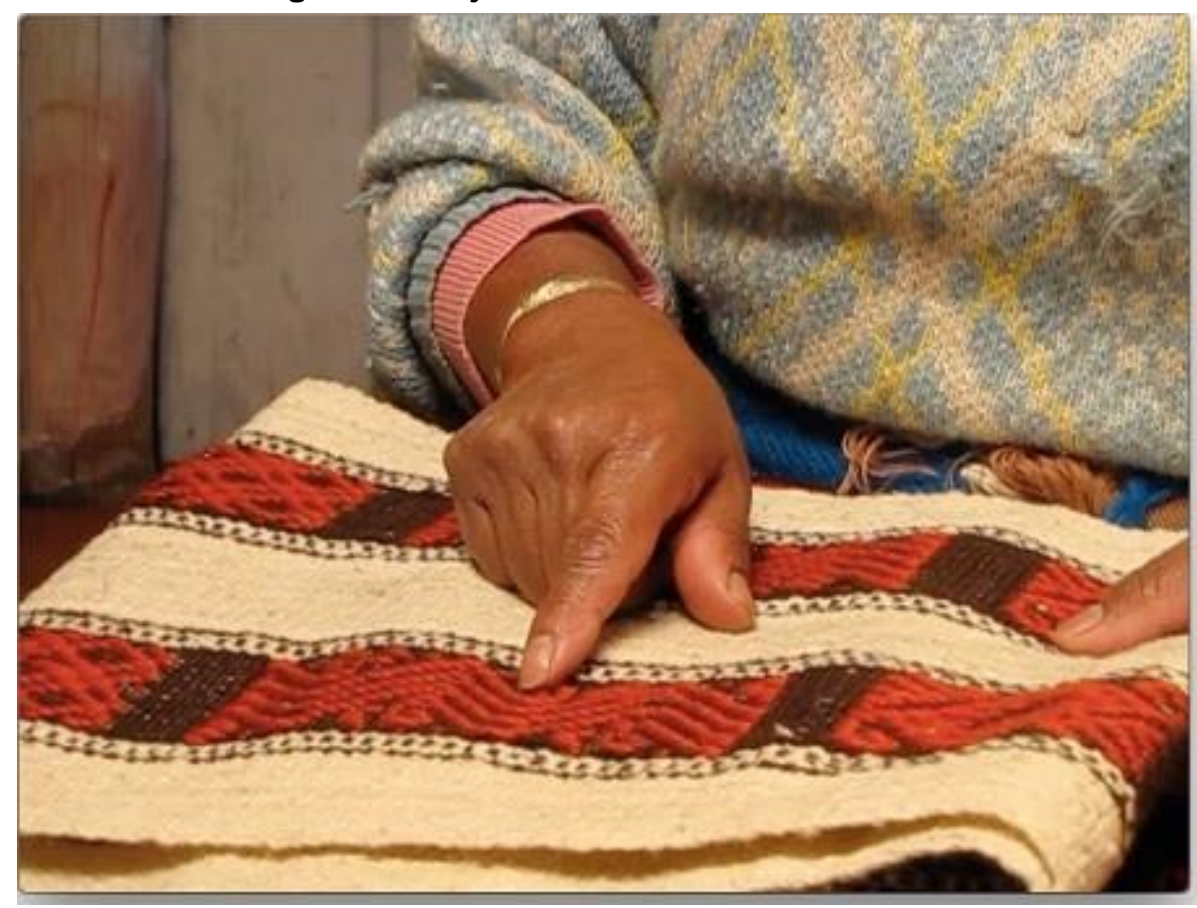

Fuente: Acervo de la autora. Polanía, R. (2009) Alto de Sibundoy, Putumayo.

El tejido tiene el poder de relatar las múltiples visiones que se tienen del mundo de los pueblos, son "gnosis liminar o pensamiento liminar", como afirma Mignolo (2003), expresión que indica una "razón subalterna luchando para la afirmación de los saberes históricamente subalternizados" (DORRICO, 2017, p. 61). Sin embargo, estas voces surgidas de los márgenes, desde los espacios subalternos borrados por las estrategias de silenciamiento, desestabilizan los asuntos de la colonialidad del poder 


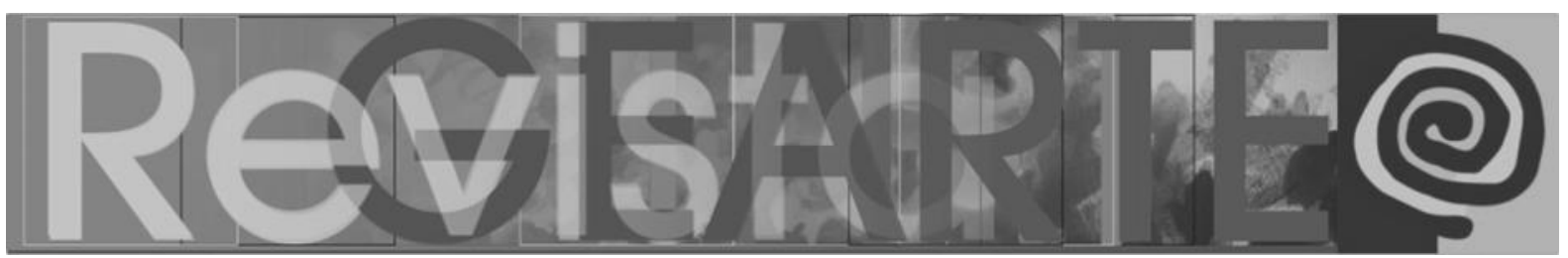

y del saber; pues si bien es cierto las prácticas artísticas nacidas de la complejidad de la tradición tiene poder performativo, lo que significa, estar abiertas a lo imprevisible, a la indeterminación de la respuesta-reacción del otro.

Estas mujeres sufren los efectos discriminatorios por ser mujeres y autodidactas, pero lo interesante de su trabajo radica en la capacidad de transitar desde lo marginal como externalidad al poder, pero también como cuestionamiento táctico de la simbólica del poder.

Figura 5 - Corona elaborada por Magdalena Chicunque, 2009

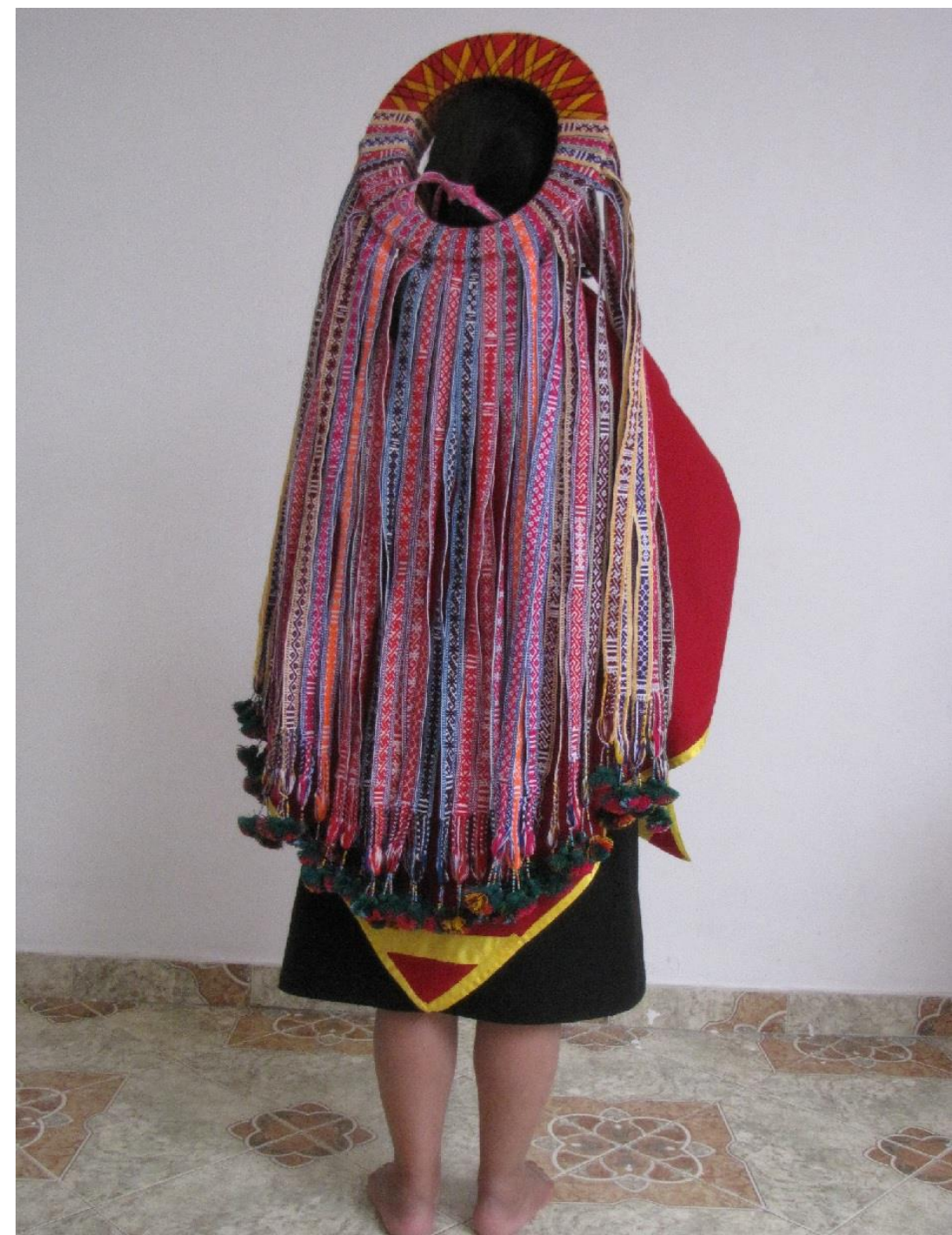

Fuente: Monroy, Edisón (2009) Alto de Sibundoy, Putumayo. 


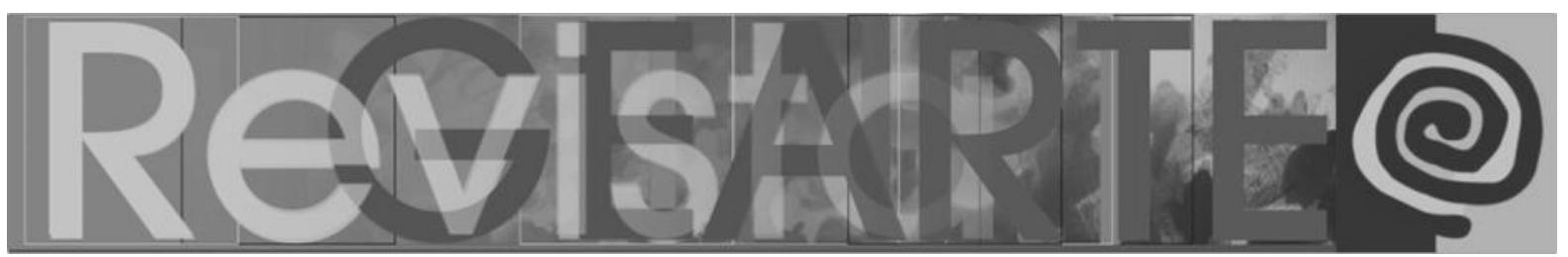

Desde esta perspectiva, el saber es construido a través del discurso tal y como lo afirman Derrida y Foucault, pues el poder del discurso se basa en la experiencia; ya no se puede considerar como una verdad simple, como algo vivido, sino que se promueve a través de una multiplicidad de verdades, todas ellas instaladas desde contextos diferentes. En esta dinámica, se precisa entonces la construcción de diálogos interculturales que rompan con las lógicas de borramiento de otros saberes, para abrir las fronteras y delinear, reafirmar, retocar o incluso deshacer las condiciones de permanencia de estos espacios que han permanecido en resistencia.

Figura 6 - Relatos tejidos. Tejedoras de Sibundoy. 13 Salón Regional de artistas. Colombia, 2009

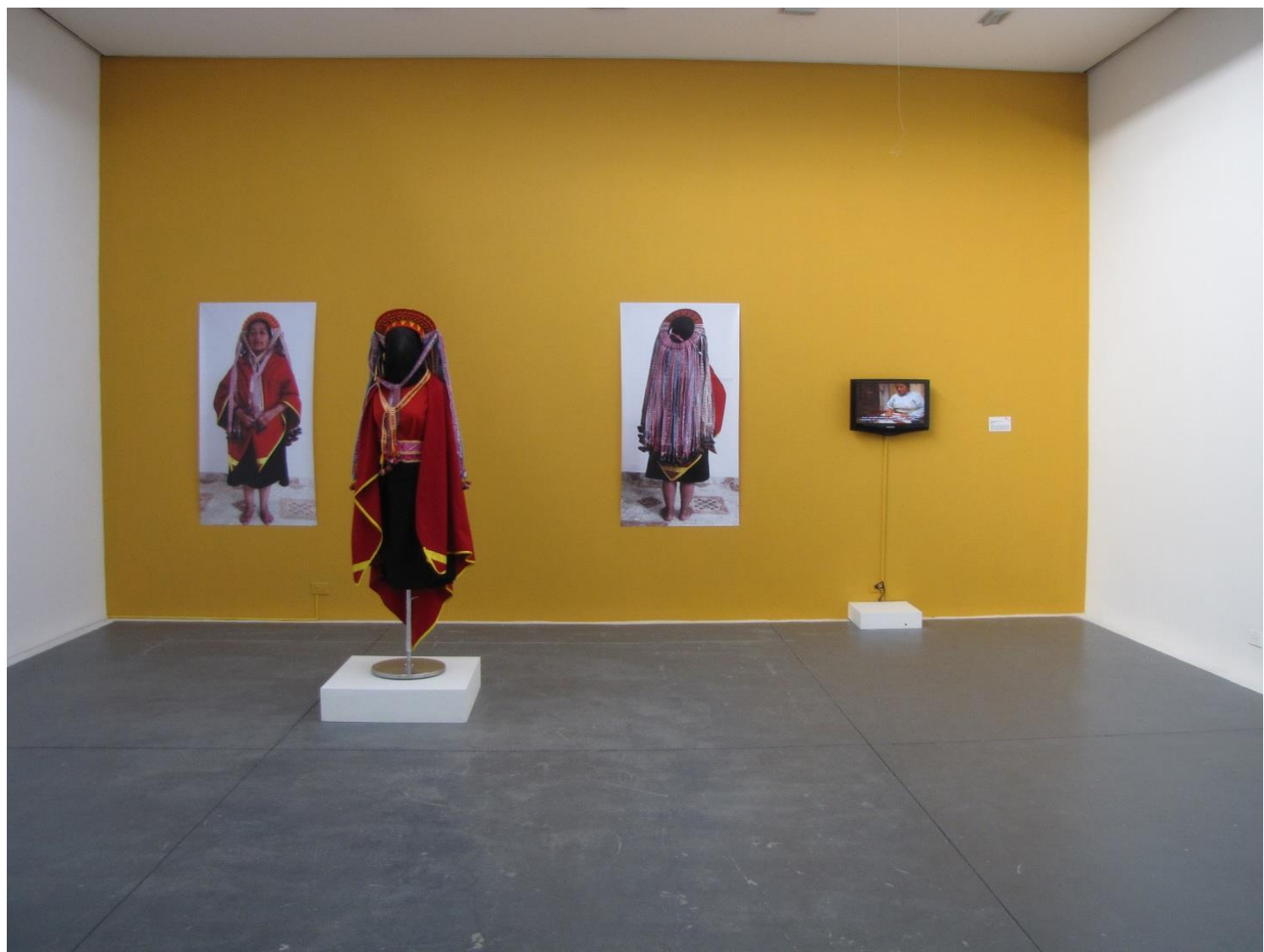

Fuente: Acervo de la autora. Polanía, R. (2009) Alto de Sibundoy, Putumayo.

En esta misma dirección encontramos a la artista Marisol Calambás, quien encuentra en las prácticas artísticas contemporáneas una manera de expresar la memoria ancestral del pueblo Nasa. Afirma la artista que "Los Nasa crecemos, heredamos una lengua y nos vemos condicionados por ese montón de cosas que nos 


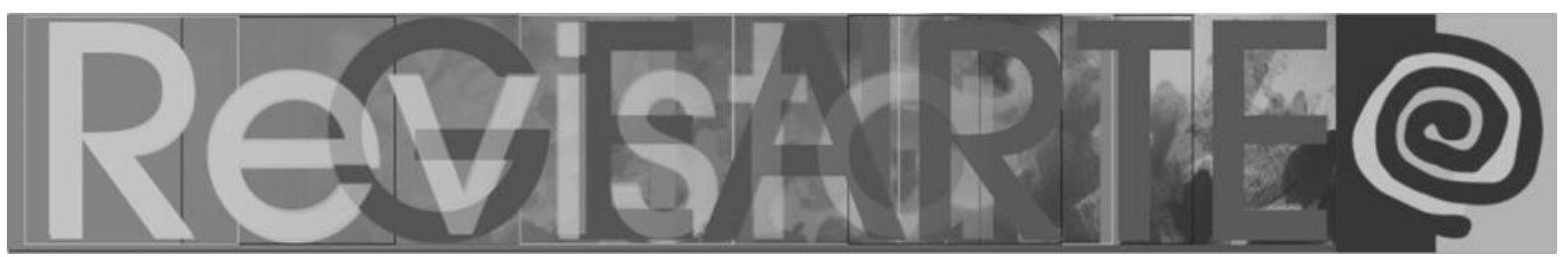

permean; cosas que no podemos negar, como lo son nuestras costumbres, nuestras formas de alimentarnos, nuestras formas de vestir" (CALAMBÁS, 2014).

La artista revela que su proyecto parte de los conocimientos que surgen de una cultura viva y de la condición humana en general, y para esto se apropia de nuevas formas de expresión, a fin de manifestar lo suyo a modo de testimonio personal, pero también con el propósito de revelar las preocupaciones de los grupos sociales subalternizados en la Región Sur de Colombia.

En esta línea basta observar la obra Lengua de gente, donde el lienzo es el cuerpo para "trazar el camino de la memoria: una espiral que sale del ombligo, la leche, la lengua, el hilo que la une a la madre, a la abuela, a la ancestralidad" (CALAMBÁS, 2014). Tal vez, la grafía son cicatrices o marcas relacionadas con el pasado, con la simbología de su pueblo, una manera de hacer visibles los lazos que la unen a su territorio.

Figura 7 - Marisol Calambás. Nasa Yuwe (Lengua de gente). Dibujo sobre el cuerpo y fotografía. $100 \times 40 \mathrm{~cm} .2013$
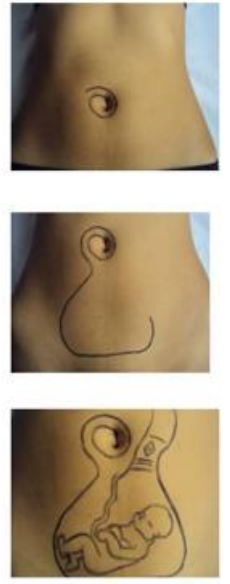
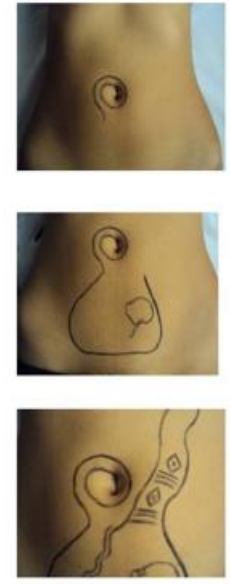

Fuente: Calambás, Marisol. (2013, p. 193)
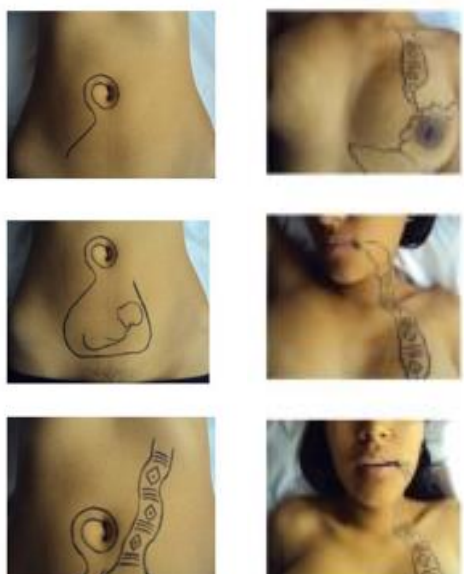
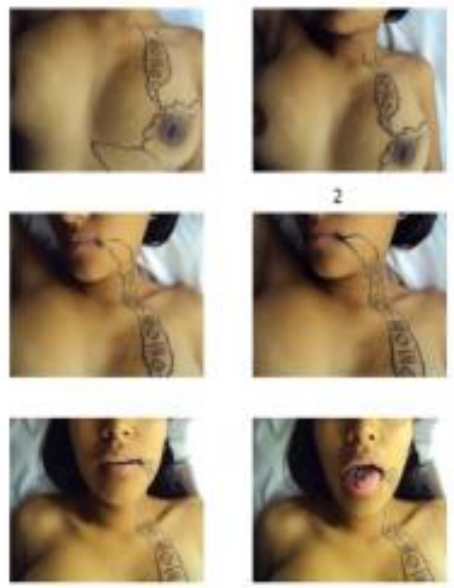
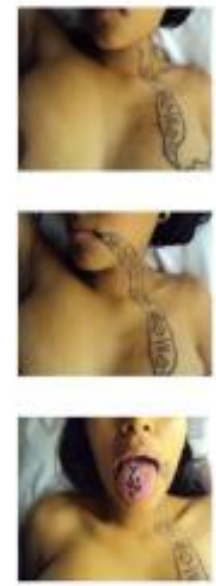

Pero también, "Lengua de gente" es un recorrido por la vida misma, una mirada atrás, a la memoria de un pueblo que ha sido opacado por la hegemonía cultural de la modernidad/colonialidad. La obra es un acto de resistencia que implica descolonizar el ser para subvertir el saber, el poder y el mirar para de esta manera, crear lógicas 


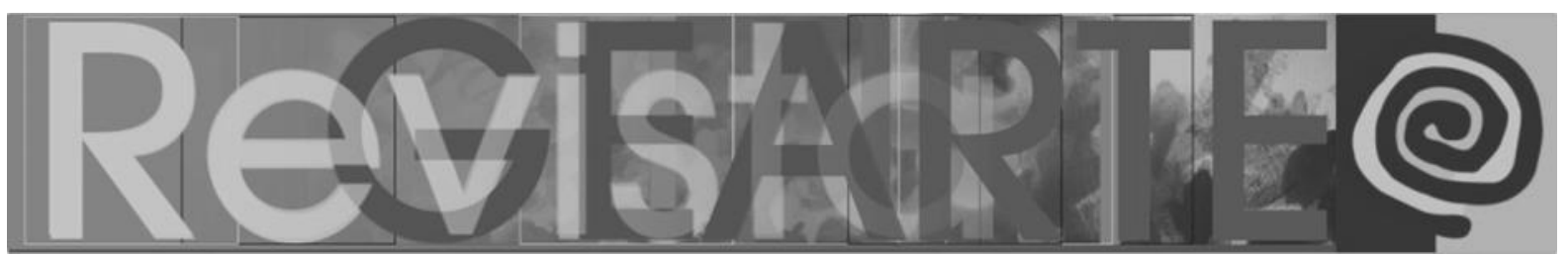

alternas y sociedades distintas que permitan despojarse de los discursos hegemónicos, tanto internos y externos, que se han generado sobre aquellos otros sujetos que habitan fuera del pensamiento colonial. Así las cosas, en la obra se presenta un diálogo de imágenes en un espacio temporal donde no existen límites, las fronteras tienden a ser cortas, de una longitud mínima que se suspende en el tiempo.

De otra parte, la artista propone en su obra otras formas de pensar el arte para dar respuesta a las condiciones del arte actual. Efectivamente, en relación con el arte contemporáneo indígena, la artista dice: "Distingo dos partes, la parte del arte y la parte del pensamiento. La pregunta es: ¿cómo se relacionan estos dos aspectos, el pensamiento milenario con el arte contemporáneo? Esta pregunta vino como una consecuencia del pasar del tiempo. Así como llegan las nuevas cosas, llegan las nuevas tecnologías, cambian las ciudades, cambian los pueblos, cambian los pensamientos. Asimismo, considero que cambia el arte. Podemos hablar del arte indígena que se expresa a través de unos medios que, quizás, para la contemporaneidad no sean los medios más establecidos, como el tejido, como la pintura corporal, la propia escultura" (CALAMBÁS, 2014, p. 191). No obstante, su propuesta es crear imágenes en las memorias de todos, indígenas y no indígenas, para que el pensamiento indígena vivo forme parte del imaginario común.

Otra artista de la región es la nariñense Ana Lucía Tumal, quien desafía el poder, lo critica y se impone a los discursos estabilizadores, a los reduccionismos e incluso a los operados por el mismo feminismo a través de su obra. Ella, por medio de la lúdica, incorpora en su obra un análisis liberador, emancipador y reivindicador de las culturas que han afrontado las dinámicas de dominación y resistencia que se desarrollan al interior de los diferentes pueblos del sur de Colombia. Su obra surge de la posibilidad de hacer "un arte participativo a través de escultura narrativa en la construcción de personajes sacados del imaginario urbano, con la posibilidad de generar un espacio de participación y de reflexión a partir de un tema como es la ciudad y lo urbano que son el punto de partida para indagar y proponer" (TUMAL; 


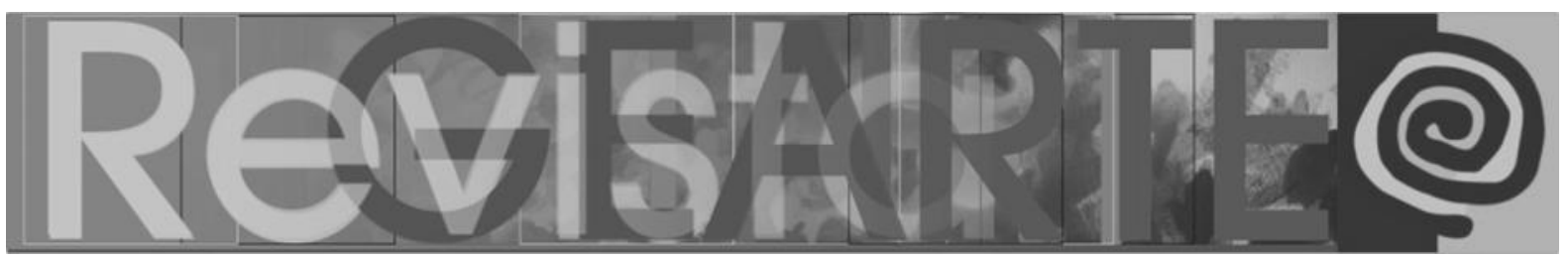

2016). La estrategia de participación creada por la artista, permite la construcción poética centrada en las relaciones humanas y sociales y generalmente pensadas por fuera de la institucionalidad del arte.

Esta mirada relacional que se manifiesta en su obra es de gran relevancia dentro del campo del arte en el ámbito regional, pues trae a la superficie las disputas y juegos de poder existentes en el contexto regional y nacional, pues si bien es cierto, a las prácticas de un artista periférico en relación a los centros de producción artística se le da menor importancia. En tal sentido, se puede afirmar que en los diferentes proyectos de Ana Lucía Tumal, existe un enfrentamiento binario no solamente entre centro y periferia, sino, además, un desafío, un choque de poderes para instalar nuevas miradas, nuevas situaciones, nuevos estados de cosas en el mundo.

Es importante ver como en la interacción del espectador con la obra permite una fruición estética que no exige un conocimiento específico del campo artístico, sino la exploración de distintas conexiones que puede establecer el individuo con el colectivo para estructurar nuevas relaciones en el espacio de la ciudad. Aquí el barro cocido es el elemento relacional, el cual puede ser interpretado como el comienzo de las luchas del hombre por dominar el espacio por medio de la historia, pero también, la pérdida del contacto del hombre con la tierra, la privación de la memoria para las nuevas generaciones. Es decir, es dejar en el olvido aquellos universos emanados de la naturaleza que junto con el hombre han urbanizado la ciudad. 


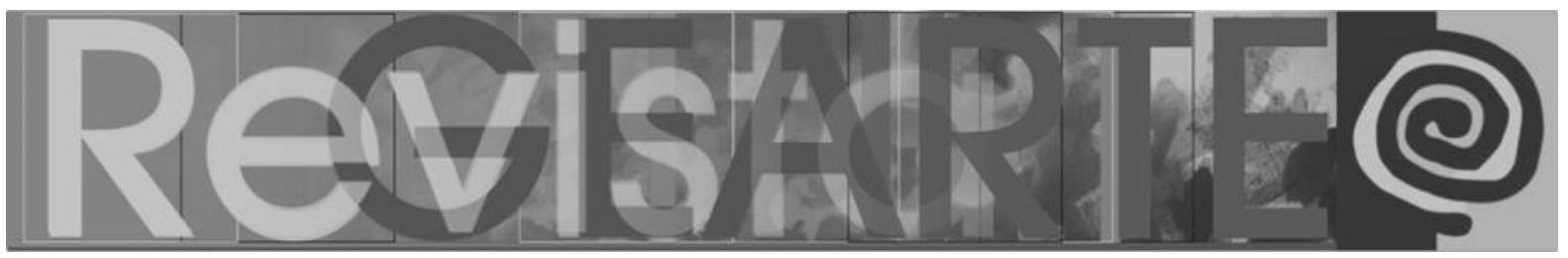

Figura 8 - Utopía. Ana Lucía Tumal, escultura instalación, 2016

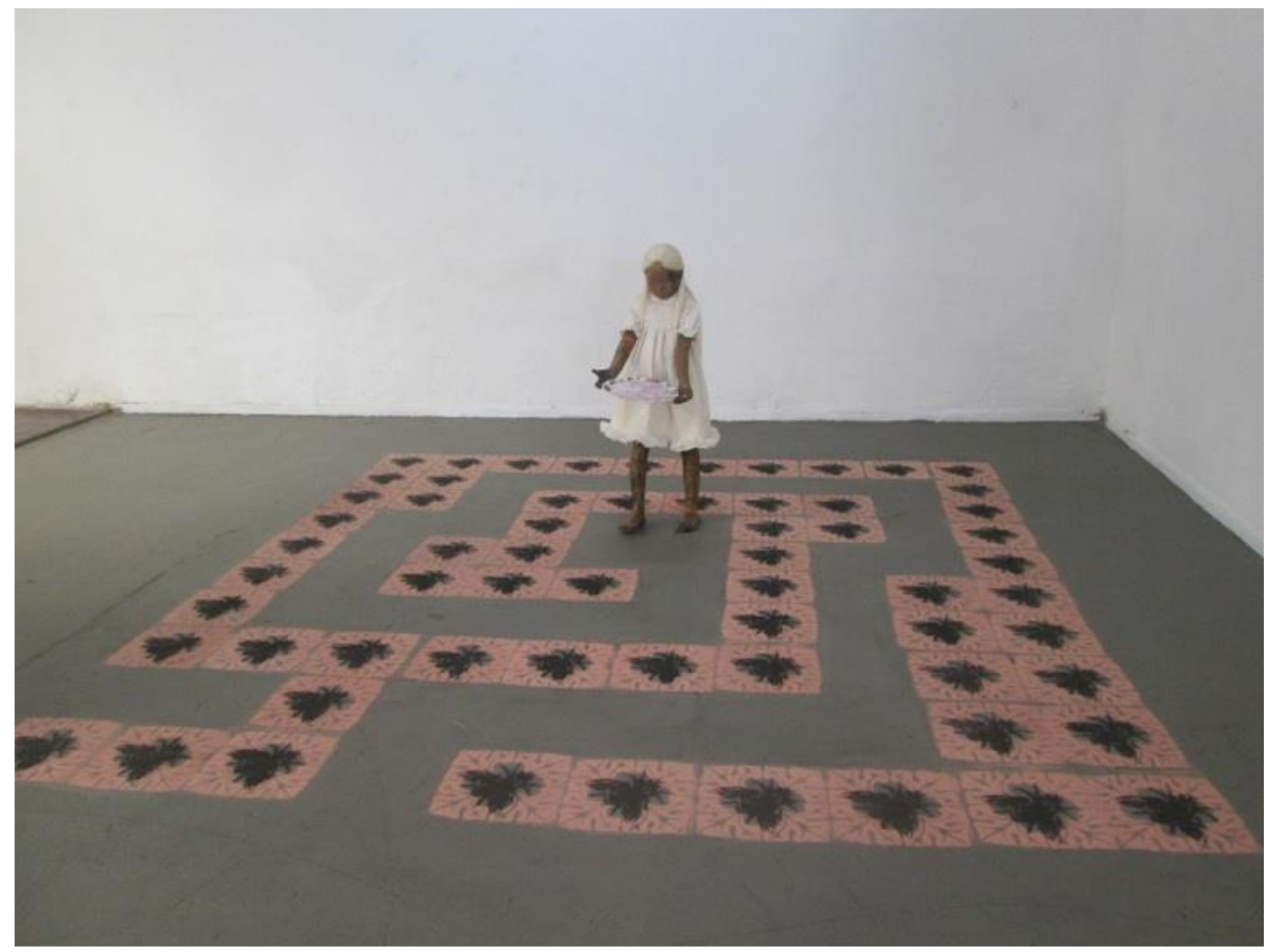

Fuente: Tumal, Ana Lucía. https://analuciatumal.tumblr.com/. Acceso en: 18 jun. 2017.

Desde esta perspectiva, Utopía "es una combinación de materia viva y barro cocido hecho con materia prima de la misma ciudad, se propone un espacio de participación, dando paso a la discusión y la aplicación de un ejercicio de compartir una semilla, ejercicio que se convierte en un claro ejemplo de construcción de alimento y entrar en el laberinto, brinda la posibilidad de entrar al mundo de la obra y conectarse con su lado natural" (TUMAL, 2016). La artista establece un diálogo entre su práctica y la materia que expresa su intención poética: el barro aquí es el origen de los pueblos, pero también es el progreso ejercido por la modernidad. 


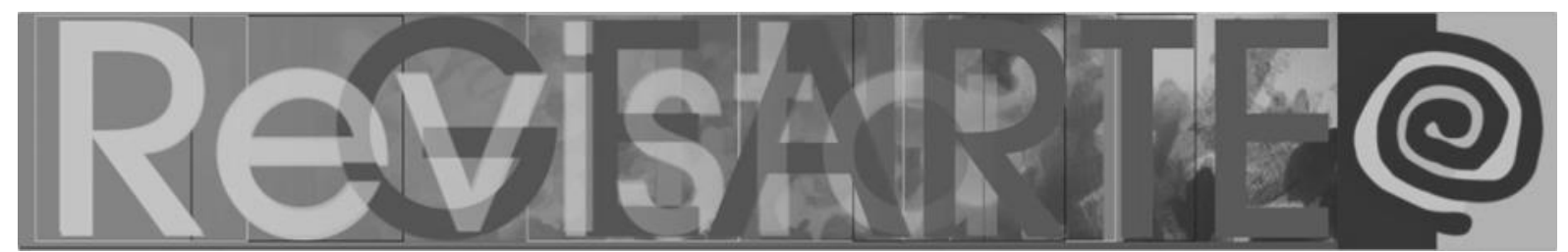

Figura 9 - La discusión de las civitas. Ana Lucía Tumal, escultura instalación, 2016

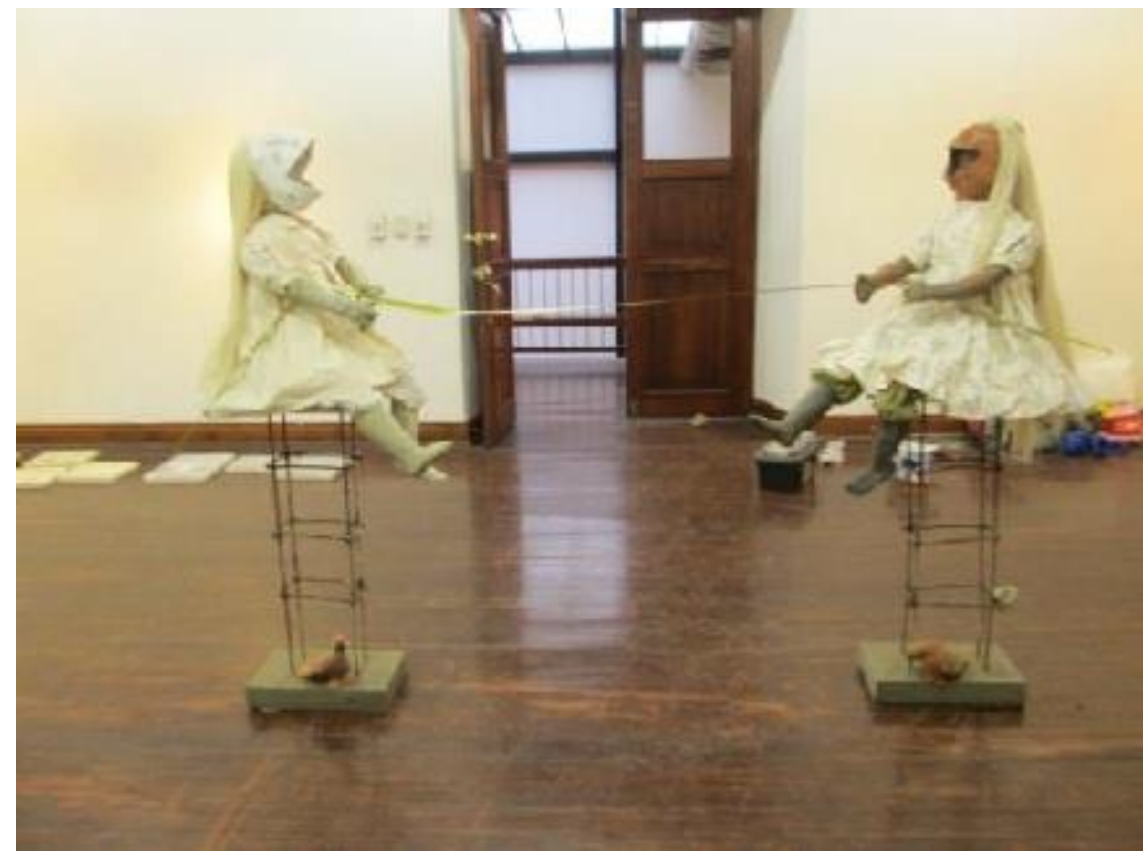

Fuente: Tumal, Ana Lucía. https://analuciatumal.tumblr.com/ . Acceso en: 18 jun. 2017.

Además, se confronta en la obra de la artista, la preocupación por realizar producciones en el que "la práctica artística aparezca como un campo fértil de experimentaciones sociales" (BOURRIAUD, 2009, p. 13); un espacio de relaciones de intercambio que termina siendo una exploración poética multisensorial, que permite la comprensión de la conciencia de la realidad urbana existente. Bajo esta mirada, los proyectos de Tumal, promueven nuevas sociabilidades y propician otras articulaciones entre los seres humanos y la naturaleza. El espectador participa en una experiencia intensa de producción de sentido, en oposición a las experiencias, tal vez, insubstanciales que le ofrece la gran ciudad. 


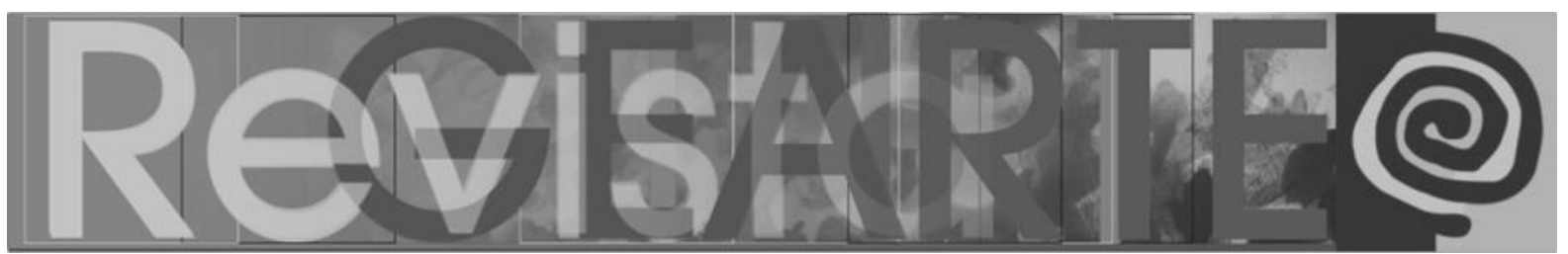

Figura 10 - Ana Lucía Tumal, Esculturas Memorias en tierra, 2015

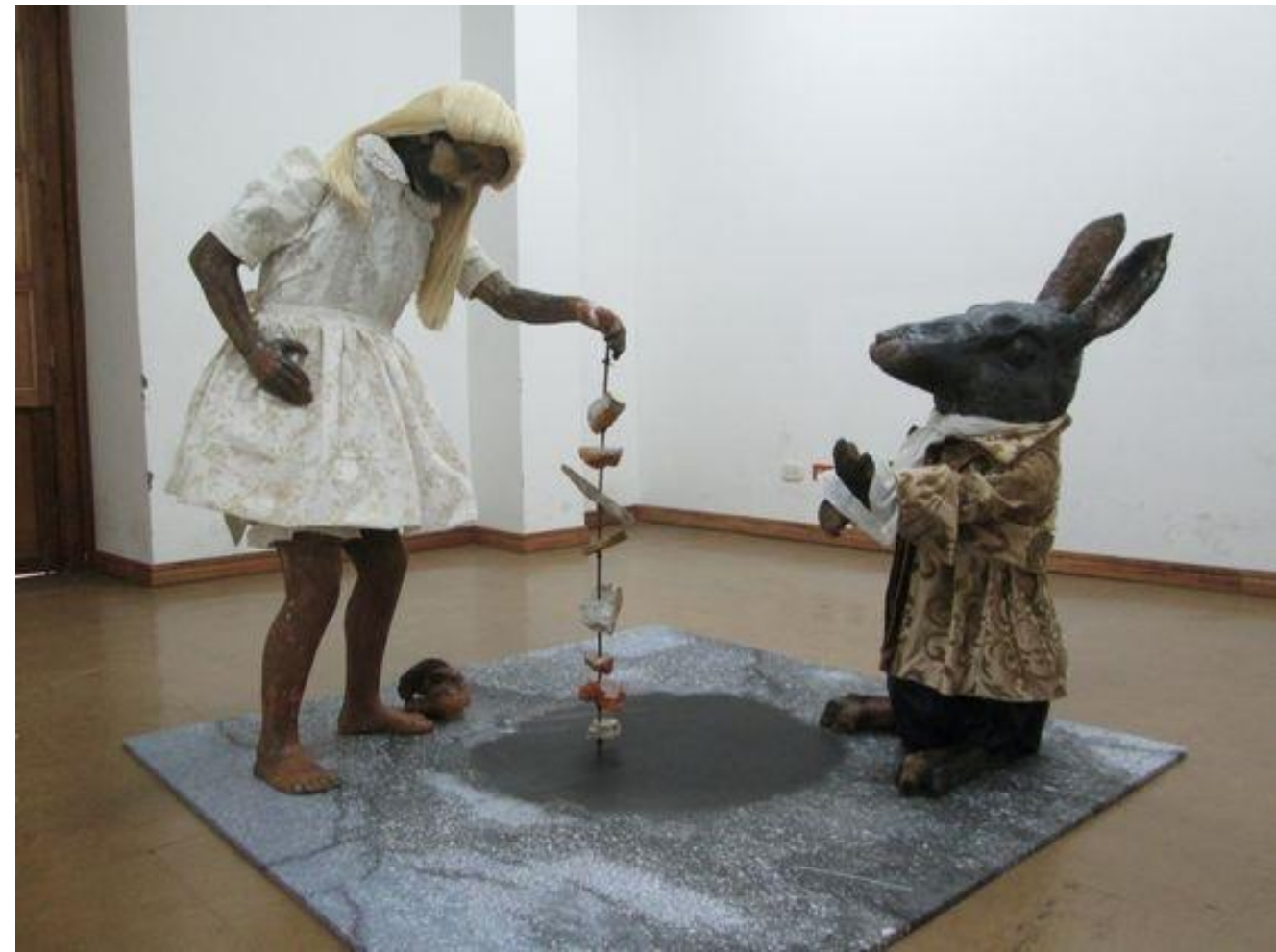

Fuente: Tumal, A. Acervo de la autora. https://www.pinterest.co.uk/pin/356558495476980987/. Acceso en: 18 jun. 2017.

Ahora bien, este grupo de creadoras, convencidas y no convencidas de su naturaleza como artistas, desarrollan otras estrategias para desafiar los mundos del arte actual intentando preservar la libertad alcanzada con sus obras. Tal vez estas mujeres gozan de distintos grados de reconocimiento social, pero sin duda, comparten problemáticas similares a la hora de enfrentarse a la tarea de elaborar un proyecto que rompe con dominios del poder y saber del conocimiento.

El papel que desempeña la mujer artista es la que tiene la capacidad de promover y visibilizar espacios y escenarios desde su condición y posición femenina a partir de una propuesta plástica en sus múltiples manifestaciones. Al respecto, Ana Lucía Tumal declara que "el papel que desempeña la mujer artista es la que tiene la capacidad de promover y visibilizar espacios y escenarios desde su visión y condición femenina a partir de una propuesta plástica en sus múltiples manifestaciones. Estos procesos no han sido gratuitos, se han venido realizando en una constante 


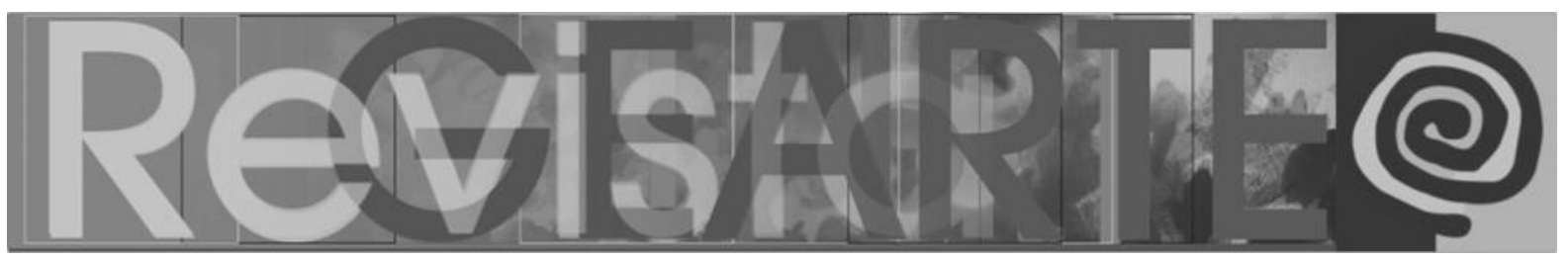

trasformación y evolución que invita a participar y a ver con otros ojos la mirada del arte" (TUMAL, 2016).

En este sentido la producción artística, tanto de mujeres indígenas o de origen mestizo, actualmente se encuentran en desplazamiento constante, ya no atada a un territorio específico. Ellas se movilizan por medio de redes transculturales en que se experimentan otras formas de entrada y salida de los discursos que imprimen otras maneras de lectura del arte, otros campos de acción más allá de un territorio, o de los mismos orígenes.

Por lo tanto, sus proyectos artísticos indagan otras respuestas construidas a partir de las interacciones que se ocasionan en el contacto entre el "nosotros" y el "ellos" evidenciando de esta manera, la pérdida de fronteras, el tránsito de imágenes y formas simbólicas que se materializan en imágenes para dar a conocer las dinámicas socioculturales de los pueblos de la Región Sur de Colombia, las cuales circulan en medio de la lucha entre la conservación de la tradición y el diligenciamiento de nuevas formas de representación.

La participación de la mujer en el arte reclama la deconstrucción del discurso de la historia del arte tradicional, para ser remplazado por otros que excluyan la discriminación y la desigualdad de géneros. Un discurso que provoque una reflexión más profunda sobre las relaciones de poder y las maneras en que las mujeres condicionan la producción, circulación y el consumo del arte actual. Quizás, negarse a aceptar la inclusión de la mujer en el arte, y específicamente a la mujer que se reconoce como indígena o mestiza, puede no ser más que un prejuicio sin ningún fundamento; pues su intencionalidad artística se funda en el rompimiento de los estereotipos vigentes frente a su participación en los sistemas artísticos y en particular ser reconocidas como artistas, pensadoras y productoras de cultura por derecho propio.

Las expresiones artísticas de la mujer de origen indígena o mestiza pueden ser consideradas como una opción decolonial, capaz de no sólo cuestionar el paradigma 


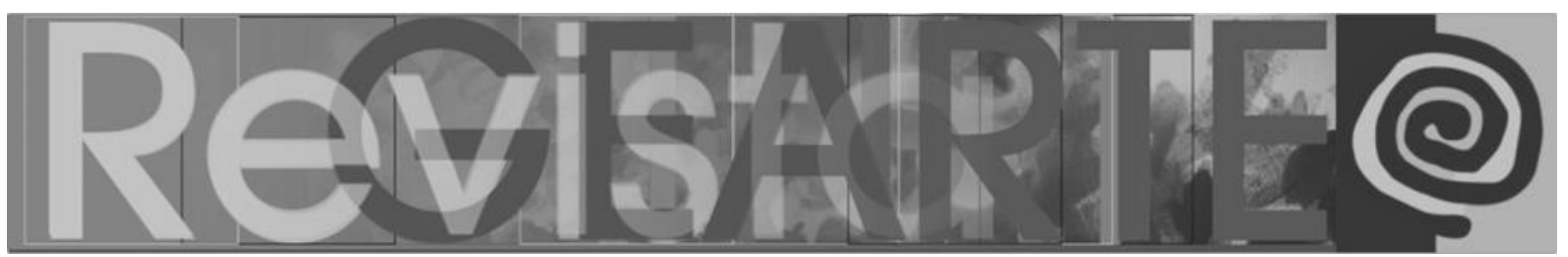

estético hegemónico, sino de crear agenciamiento que le permitan liberarse de los moldes que la han mantenido en la exclusión, la invisibilidad y posición de desigualdad. Pero ante que todo, pueden convertirse en escenarios para romper los marcos que nosotras mismas hemos creado por temor a exigir los mismos derechos y las mismas condiciones que poseen nuestros pares.

En este sentido, la importancia de visibilizar a la mujer en las artes requiere abrir un nuevo y fecundo escenario que apunte a la diversidad de miradas, escenarios que le apuesten a la construcción de desafíos teóricos y políticos para esos otros escenarios estéticos invisibilizados por el pensamiento de la modernidad/colonialidad, el cual a través del devenir histórico tan solo ha reforzado la mirada hacia la exclusión en términos de raza, etnias, sexualidad, clases sociales. De hecho, la inclusión de la mujer de origen indígena o mestiza trae consigo provocaciones relacionadas no solo con el género y los sistemas patriarcales, sino también con aquellos relacionados con el poder, el Estado, la economía y los Derechos Humanos. Todo esto debido a que el mundo creado por la mujer a través del arte se constituye en una critica profunda a la colonialidad del poder y del saber ante los cuales miles de mujeres todavía resisten. De esta manera, el reconocimiento de la mujer indígena o mestiza pensada desde el sur geopolítico de Colombia en el arte, dan razones reveladoras para la construcción de otras epistemologías que se opongan a las dominantes y pongan en entredicho el panorama de la historia del arte eurocéntrico.

\section{Referencias}

ARENDT, Hannah. Sobre la violencia. Madrid: Alianza Editorial S.A., 2005-2006.

BOURRIAUD, Nicolas. Estética relacional. São Paulo: Martins Fontes, 2009.

BUTLER, Judith. Mecanismos psíquicos del poder. Madrid: Feminismo, 2010.

CALAMBÁS, Marisol. No sólo crear la memoria de nosotros como pueblos indígenas, sino enseñar a ver esa memoria. Mundo Amazónico, Bogotá, v. 5, ene-dic, p. 189-195, 2014.-ISSN electrónico 2145 5082. Disponible en: https://revistas.unal.edu.co/index.php/imanimundo/article/viewFile/45789/48331. Acceso en: 18 jun. 2017.

CAMPERO, María Belén. Un individuo-sujeto: el yo como una unidad compleja. Revista de Filosofía, UCM, v. 42, n. 1, p. 135-151, 2017.

DORRICO, Julie. Alteridade indígena: voz-práxis via literatura em A Queda do Céu: palavras de um Xamã Yanomami. Revista Opinião Filosófica, Porto Alegre, v. 8, n. 01, p. 59-72, 2017.

POLANÍA FARFÁN, Rocío. Entre el saber y el poder: mujeres en el 428 contexto del arte actual en la región sur de Colombia.

Revista GEARTE, Porto Alegre, v. 6, n. 2, p. 410-429, maio/ago. 2019.

Disponível em: http://seer.ufrgs.br/gearte 


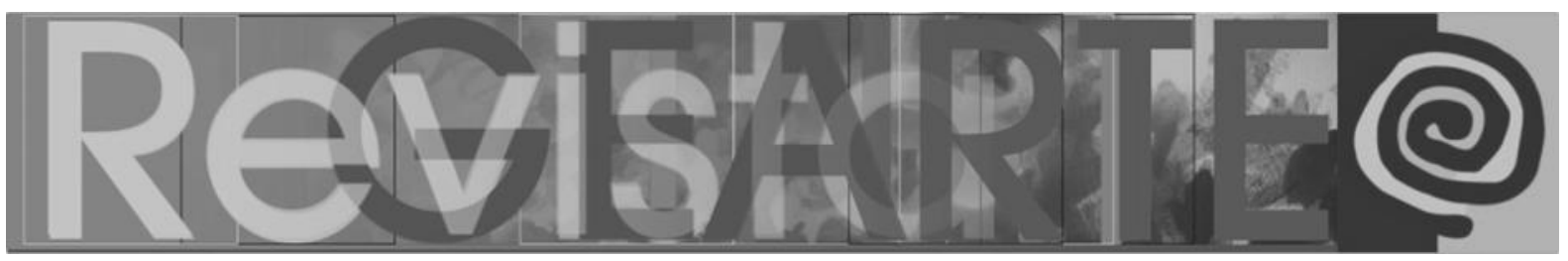

FOUCAULT, Michel. Historia de la sexualidad: el uso de los placeres. Buenos Aires: Siglo Veintiuno, 2010.

MIGNOLO, Walter D. Histórias locais/ projeto globais: colonialidade, saberes subalternos e pensamento liminar. Tradução de Solange Ribeiro de Oliveira. Belo Horizonte: Editora UFMG, 2003.

MILLET, Kate. Política sexual. Madrid: Cátedra, 1995.

POLANÍA, Rocío Farfán. Sonidos, ecos y silencios de la región sur. Colombia. 2009. La Nación. ISSN. 1900-0022 p.2B - 2B v.5296

TISOY, Rosa. Web oficial. Disponible en: https://rosatisoy.wixsite.com/rosy-tisoy- . Acceso en: 18 jun. 2017.

TUMAL, Ana Lucía. Web oficial. Disponible en: https://analuciatumal.tumblr.com/ . Acceso en: 18 jun. 2017.

\section{Rocío Polanía Farfán}

Doutora em Estudos Sociais pela Universidad Externado da Colômbia. Professora Associada e pesquisadora do curso de Licenciatura em Educação Artística da Faculdade de Educação da Universidade Surcolombiana. Desenvolveu processos de inovação e pesquisa pedagógica nos campos da educação, arte e cultura. Atualmente pertence ao grupo de Investigação ALTERARTE, categoría B de Colciencias.

E-mail: rocio.polania@usco.edu.co

Currículo: http://scienti.colciencias.gov.co:8081/cvlac/visualizador/generarCurriculoCv.do?cod_rh=0 001138049

Recebido em 20 de abril de 2019 Aceito em 18 de maio de 2019 